\title{
CD2 Expressing Cell to Lymphocyte Ratio Measurement
}

National Cancer Institute

\section{Source}

National Cancer Institute. CD2 Expressing Cell to Lymphocyte Ratio Measurement. NCI

Thesaurus. Code C103367.

The determination of the ratio of CD2 expressing cells compared with the total number of lymphocytes in a sample. The measurement may be expressed as a ratio or percentage. 